as shown by measurements of the incorporation of carbon-14, we have found them inert to insulin by the criterion of measurements of the respiratory quotien $t^{2}$. Secondly, we have observed effects due to cortisone on the composite respiration curve of mammary gland slices from 20-day pregnant rats, which surprisingly are in the opposite direction from that expected from the carbon-14 measurements, cortisone changing the gradually falling composite curve, characteristic of slices taken at the end of pregnancy, into a rising on $e^{7,8}$. Evidently the well-authenticated interpretation of the composite curve, which applies to experiments with fully-lactating tissue, does not hold for tissue taken at the end of pregnancy. Further experiments, now in progress, may clear up this apparent discrepancy.

We are indebted to Dr. Helen Porter, of the Research Institute of Plant Physiology, Imperial College of Science and Technology, for the preparation of the carbon-14 starch, from which the labelled glucose was made, to Dr. K. Hallas-Møller, of Novo T'erapeutisk Laboratorium, Copenhagen, for crystalline insulin free from glycogenolytic factor, and to Dr. C. C. Porter, of the Merck Institute for Therapeutic Research, Rahway, N.J., for crystalline cortisone (free alcohol). We are also indebted to Mr. B. W. E. Peaple for skilled technical assistance.

\footnotetext{
${ }^{1}$ Balmain, J. H., French, T. H., and Folley, S. J., Nature, 165, 807 (1950).

2 Jalmain, J. H., and Folley, S. J., Biochem. J., 49, 663 (1951).

${ }^{3}$ Balmain, J. H., Folley, S. J., and Glascock, R. F., Nature, 168, 1083 (1951)

4 Brady, R. O., and Gurin, S., J. Biol. Chem., 186, 461 (1950).

${ }^{5}$ Brady, R. O., Lukens, F. W. D., and Gurin, S., J. Biol. Chem., 193, 459 (1951).

${ }^{\circ}$ Balmain, J. H., Folley, S. J., and Glascock, R. F., Biochem. J. (in the press).

"Balmain, J. H., and Folley, S. J., Arch. Biochem. (in the press).

${ }^{8}$ Folley, S. J., "Recent Progress in Hormone Research", " 7 (in the

${ }^{8}$ Dickens, F., and Simer, T., Biochem. J., 25, 973 (1931).

${ }^{10}$ Glascock, R. F., Nature, 168, 121 (1951) ; Nucleonics, 9, 28 (1951).
}

\section{SCIENCE FOR PEACE}

A CONFERENCE was held during January 19-20 in London of the organization Science for Peace, which was attended by 180 scientific workers.

In opening the first session Prof. F. G. Gregory reviewed the work of the provisional committee formed just a year ago, and reported that sufficient support has been secured among men of science to call this conference to reconsider the principles laid down and to place the organization on a permanent national footing.

Mr. F. le Gros Clark introduced a discussion of principles. He stressed the moral responsibilities of the man of science for the use to which scientific discoveries are put. The public, he said, looked to the scientist for enlightenment, and were apt to blame him for the apprehensions which they feel. "We can no longer pretend to be simpletons experimenting and designing for the mere love of the work in a world that will forgive us if one day the roof blows off. In this situation is it not our responsibility to give what guidance we can ?"

After lengthy discussion, a statement of principles was adopted. Recognizing the danger of a third world war the statement runs, "we are determined to do what we can both as citizens and as scientists to prevent it, and to re-establish peace throughout the world. We think it our duty to ensure that science is used solely to improve the conditions of life and to advance the arts of peace". It is the scientist's duty "to inform and enlighten the public both about the benefits that science can bring, and about the destructiveness and misery of modern war; to make what contribution he can towards an understanding of present international tensions; and to urge peoples and governments to work for a negotiated, reasoned and enduring settlement that will prevent a recourse to the increasingly destructive weapons of another war". The statement ends: "We assert the permanently international character of science. It is a world-wide republic of the mind. The scientists of all countries form one fraternity united in a common effort to understand nature; they could be united in a common concern for human betterment. We must seek to maintain everywhere the civil rights of scientists; and it is our duty to strive for the removal of all barriers that restrict or embarrass the free intercourse of scientists and the free interchange of scientific information throughout the world".

In the second session, Prof. K. Lonsdale spoke on the activities to be pursued. She recounted her own experiences in different peace organizations over the past thirty years, and emphasized the importance of each individual facing squarely his or her own personal responsibilities. Scientists must be prepared to talk to groups of all kinds, to do this themselves and not to rely upon a few distinguished speakers. What people want to hear about is not the horrors of atomic warfare, not the A.B.C. of atomic energy, but dispassionate analyses of present deadlocks, and expert suggestions as to what can be done about it. The discussion which followed concerned the formation of local groups of Science for Peace in universities and other laboratories, to hold discussions at which policy questions can be resolved and to organize meetings and other activities whereby agreed policies can be carried to other scientists and to the general public. The Bulletin already issued by the provisional committee is to be continued.

In the third session two important resolutions were passed, the first concerning biological warfare. Taking due regard that research directed to defence against biological attack presupposes simultaneous research into the use of biological weapons, and that, particularly when conditions of secrecy are imposed, it may not be possible to prevent such knowledge from being applied, the resolution calls on H.M. Government :

(1) to enter into negotiation with other Governments with the view of a general formal repudiation of any use of biological warfare and to working out practical measures to ensure that this repudiation is effective ;

(2) to refrain from imposing conditions of secrecy upon workers at any government-sponsored research institute engaged in work which might bear upon the problems of biological warfare; and to allow inspection of such institutes by accredited representatives of a recognized international organization ;

(3) to secure the full publication of the results of all such research, including secret work already completed, whether or not it was directly concerned with biological warfare.

Recommendations (2) and (3) were contingent on recommendation (1) ; unilateral abrogation of all secrecy was not intended. 
A second motion directed attention to the essential need for the elimination of atomic weapons and for a strict international control and inspection of atomic installations. It stated that the differences in policy on international control between the various countries are not as great as has sometimes been suggested and are capable of resolution by compromise. It continued: "In particular, the stress that has been laid on international ownership of large-scale atomic establishments is not justified. Although such ownership might facilitate control it is not essential for effective control. Since it constitutes a major stumbling block we respectfully suggest to our Government that it should use its influence to secure that this proviso is not allowed to hold up a general agree. ment".

Further resolutions were passed establishing a National Committee and deciding that membership shall be open to natural and social scientists, technologists, engineers and technical assistants and to students taking appropriate courses. Members may join individually or through groups. The twenty-five members of the National Committee include Prof. L. Rosenfeld, Prof. A. C. Offord, Prof. F. G. Gregory, Mr. N. W. Pirie, and Prof. J. D. Bernal. Prof. Kastler and Dr. Grillot were present as fraternal delegates from the French organization "Mouvement des Universitaires Français devant la Menace d'une Nouvelle Guerre Mondiale". Both addressed the conference, and stressed that peace organizations must achieve extensive international contacts.

Summing up the conference, Prof. C. F. Powell said that the whole of West-European scientific tradition from the time of Bacon and Descartes is based on the view that by means of science it is possible to enrich life. The current tendencies towards secrecy and victimization may sap our scientific life like a wasting disease and completely undermine the scientific traditions of Great Britain. In so far as we contribute to the release of tension among the nations, we contribute not only to the safety and independence of our country, but also to the support and sustenance of the great scientific tradition in which we have been fostered and to removal of the suspicion that scientists are indifferent to the often revolutionary consequences of their own discoveries. F. G. GREGORY

\section{ABRASION AND WEAR OF MATERIALS}

A

SYMPOSIUM on the "Abrasion and Wear of Materials" was held under the auspices of the British Society of Rheology on January 4 at the Polytechnic, Regent Street, London. Of the six papers delivered, three, read in the first session, dealt with hard inorganic materials; the remaining three were devoted to the abrasion and wear of rubber, textiles and leather.

The symposium was opened by M. W. Thring (British Iron and Steel Research Association, London), who was chairman for the morning session. In the afternoon, Dr. V. G. W. Harrison (Printing, Packaging and Allied Trades Research Association, Leatherhead) was in the chair. In the first paper, P. Grodzinski (Diamond Research Laboratory, Industrial Distributors, Ltd., London) described "Three Years Experience with a New Micro-Abrasion Tester". Mr.
Grodzinski has developed a tester, primarily for determining vector-hardness differences in diamond surfaces, which has, however, proved useful for most hard materials. The equipment comprises essentially a sharp-edged, doubly conical wheel of 1 in. radius, made of sintered carbide impregnated with diamond dust and revolving at 10,000-15,000 r.p.m., against the edge of which the sample is pressed by a balance arm at low load. The dimensions of grooves cut in 1-15 sec. at given pressures serve as measures of hardness, and in the case of hard materials such as diamonds, rubies and carbides, these are linearly related to their hardness as determined by conventional methods.

Dr. K. H. R. Wright (Mechanical Engineering Research Organization, Department of Scientific and Industrial Research, Glasgow), in a paper entitled "Fretting Corrosion", described a series of experiments of a fundamental nature, in which he carefully controlled environmental and mechanical conditions such as humidity, surface adsorption of oxygen, etc. The oxide initially formed in the fretting corrosion of steel was $\mathrm{Fe}_{3} \mathrm{O}_{4}$, but ultimately $\alpha-\mathrm{Fe}_{2} \mathrm{O}_{3}$ was found. Experiments were carried out with steel submerged in British Pharmacopoia paraffin which was either free from water or saturated with it. In each case the formation of $\alpha-\mathrm{Fe}_{2} \mathrm{O}_{3}$ could be inhibited, but this was not possible if the metal was immersed in $n$-hexane, an inert liquid with a high content of dissolved oxygen. Lubricated, phosphated steel surfaces were very resistant to fretting corrosion, but nickel-plating, contrary to belief, was ineffective as inhibitor.

A paper entitled "The Wear of Wire-Drawing Dies" was read by J. G. Wistreich (British Iron and Steel Research Organization, Sheffield), whose research is directed towards reducing materially the frequency of failure of sintered-carbide wire-drawing dies, for failure is at present a source of considerable economic loss by causing periods of enforced idleness in wiredrawing mills. The most serious form of failure is 'ringing', in which ring-shaped cavities are formed near the die entry and exit. Carbide grains loosened in that region detach themselves on drawing the wire, scoring the latter in the process and facilitating damage to subsequent dies. Evidence from a statistical analysis of die-failures shows that, although short die-lives are prevalent in the correlation of frequency with lengths of die-lives, a tail exists in the distribution curve at its long-lives end. This indicates that a practical solution might be found, most probably by improving the methods and means of die-lubrication.

Speaking on "Elementary Aspects of Rubber Abrasion", Dr. A. Schallamach (British Rubber Producers Research Association, Welwyn) said that the scratch-traces produced by the movement of a loaded needle, and the corresponding tractive forcetime records, depend pronouncedly upon the nature of the compounds under investigation. Traces on pure gum vulcanizates are always continuous, but those on carbon-loaded compounds of the tyre-tread type are discontinuous. Abrasion patterns have proved to be an important clue to the actual mechanisms by which abrasion of tyres occurs on the road.

Dr. T. H. Morton (Courtaulds, Ltd., Bocking, Essex), in a paper on the "Wear and Abrasion of Textiles", said that, since the application of an abrasive to a textile material can produce a hole similar to that resulting from wear, there exists a tendency to equate abrasion with wear, though it is 